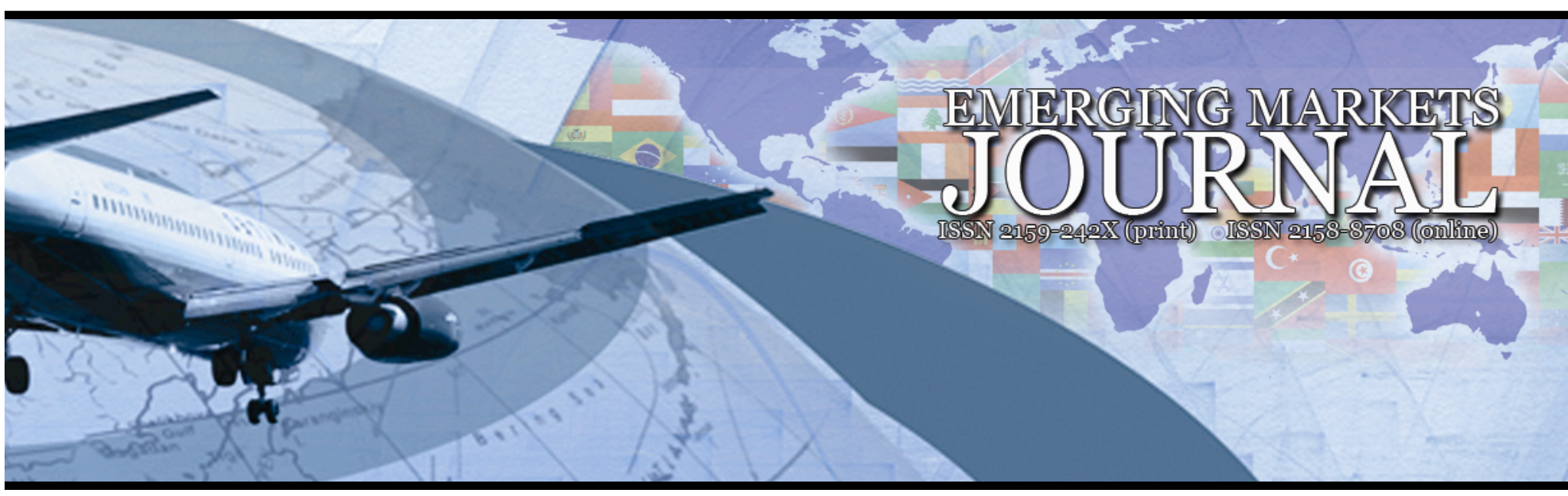

\title{
THE EFFECTS OF CONSUMER ETHNOCENTRISM AND CONSUMER ANIMOSITY ON THE RE-PURCHASE INTENT: THE MODERATING ROLE OF CONSUMER LOYALTY
}

\section{Sukru Akdogan}

Erciyes University | e-mail: akdogans@erciyes.edu.tr

Metin Kaplan

Nevsehir University

\author{
Sevki Ozgener \\ Nevsehir University \\ Aysen Coskun \\ Nevsehir University
}

Volume 2(2012) ｜ ISSN 2158-8708 (online) | DOI 10.5195/emaj.2012.15 | http://emaj.pitt.edu

Abstract

With the growth of international trade and travel, consumers are increasingly confronted with foreign products and services. But some negative attitudes towards foreign products can arise from several factors such as previous or ongoing political, military, economic, or diplomatic events. Thus, both consumer ethnocentrism and consumer animosity have become important constructs in marketing. The purpose of this study is to investigate whether consumer ethnocentrism and consumer animosity affect repurchase intent towards U.S. products and whether this impact is moderated by customer loyalty. The findings of the research indicate that consumer ethnocentrism increases consumer animosity for the sampling. The present study also denotes that both consumer ethnocentrism and animosity have a negative impact on repurchase intent toward U.S. products in Turkey. According to the results of regression analyses, customer loyalty may not be an important moderating factor between consumers' animosity and repurchase intent toward U.S. products. However, customer loyalty moderated the relationship between consumer ethnocentrism and repurchase intent toward U.S. products. Further implications for Turkish consumers in supermarkets in the province of Nevşehir are discussed. The value of future research is also acknowledged.

Keywords: Consumer ethnocentrism, Consumer animosity, Customer loyalty and Repurchase Intent

\section{(C) I EY-NC-ND}

This work is licensed under a Creative Commons Attribution-Noncommercial-No Derivative

Works 3.0 United States License.

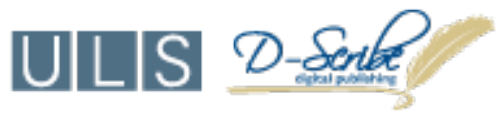

This journal is published by the University Library System of the University of Pittsburgh as part of its D-Scribe Digital Publishing Program, and is cosponsored by the University of Pittsburgh Press 
The Effects Of Consumer Ethnocentrism And Consumer Animosity On The RePurchase Intent: The Moderating Role Of Consumer Loyalty

\author{
M. Sukru Akdogan \\ Sevki Ozgener \\ Metin Kaplan \\ Aysen Coskun
}

\section{Introduction}

Ethnocentrism and animosity as concepts associated with marketing management and organizational behavior are fairly new.

Both ethnocentrism and animosity are variables associated with the origin of a product. Ethnocentric consumers believe that buying foreign products hurts the domestic economy and national employment. Animosity refers to remnants of antipathy, or hostility towards a country (Jimenez and San Martin, 2010: 34-45).

Consumer ethnocentrism and consumer animosity are considered to have an influence on customers' perception of the goods and services offered. In fact, consumer animosity and consumer ethnocentrism have a negative effect on customers' repurchase intent to foreign products. But it is commonly known that there is a positive relationship between customer loyalty and repurchase intent. In this context, the goal of this study is to investigate the moderating role of customer loyalty on the relationships between consumer animosity - consumer ethnocentrism, and repurchase intent toward U.S. products.

\section{Consumer Ethnocentrism}

Ethnocentrism has a negative influence on the evaluation and purchasing intentions of consumers, although that may vary within cultures and between different country-of-origin products (Jiménez Torres and San Martín Gutiérrez, 2007: 67).

Shimp and Sharma (1987) apply ethnocentrism to the study of marketing and consumer behavior. They defined consumer ethnocentrism as a belief held by consumers on the appropriateness and indeed morality of purchasing foreign-made products. Consumer ethnocentrism implies the normative belief that purchasing domestic products is more beneficial than purchasing foreign goods.

Previous studies found that scores on the CETSCALE are related inversely to willingness to purchase imports, perceptions of the quality of imported goods, cultural openness, education, and income (Shimp and Sharma, 1987; Netemeyer et al., 1991). Particularly, consumers who hold strong ethnocentric beliefs are more likely to evaluate foreign products negatively than are those who do not hold such beliefs. Those who believe that it is wrong to buy foreign goods also tend to perceive those goods as lower in quality than domestic goods; ethnocentric consumers prefer domestic goods not only because of economic or moral beliefs, but also because they believe that their own country produces the best products (Klein et al., 1998: 92).

In the minds of ethnocentric consumers, the purchase of foreign-made products is wrong because it hurts the domestic economy, causes loss of jobs, and is unpatriotic. Therefore, it is anticipated that ethnocentric consumers tend to be 
biased towards domestic products (Evanschitzky et al. 2008: 9). Ethnocentric consumers will tend to reject people, symbols and values that are culturally dissimilar, while intra-cultural objects will become recipients of pride and attachment (Herche, 1994: $6)$.

Consumer ethnocentrism is positively related but distinct from consumer animosity. Klein and Ettensen (1999) suggest that consumer ethnocentrism contributes to a consumer's propensity to avoid buying foreign products in general, while animosity is directed towards a specific country (Rose et al., 2009: 331). However, there are limited numbers of studies on consumer ethnocentrism and repurchase intent to foreign goods and services in Turkey.

\section{III.Consumer Animosity}

With the growth of international trade, an increasingly diverse array of products of different national origins is now available in many countries throughout the world. This has resulted in greater interest in examining consumer attitudes towards products of different national origins. Because consumer ethnocentrism and consumer animosity substantially affect the multinational firms' investment decisions and foreign capital flows. Most research has been conducted in large industrialized countries such as the US, France, Germany, and Chinese those have large internal markets and a wide range of domestic alternatives or brands in most product categories (Klein et al., 1998; Witkowski, 2000: Nijssen and Douglas, 2004; Bahaee and Pisani, 2009). There are a few studies related with consumer ethnocentrism and consumer animosity in Turkey.

Consumer animosity is defined as the remnants of antipathy related to previous or ongoing political, military, economic, or diplomatic events - will have a direct, negative effect on consumers' purchase behavior in the international markets (Ettenson and Klein, 2005; Riefler and Diamantopoulos, 2007).

Consumer animosity refers to strong negative emotions toward purchasing products from a disliked nation or group. The majority of consumer animosity studies have examined the attitudes of the members of one nation towards the products of another nation (Rose et al., 2009: 330). Examples are numerous and range from reports of Jewish consumers avoiding the purchase of German-made products to the boycott of French products by Australian and New Zealand consumers because of the recent nuclear tests made by France in the South Pacific (Klein et al., 1998: 90). If consumers think a foreign nation damages their own country, they will be likely to show animosity towards that specific country. The emotional nature of animosity shows how international tensions can have repercussions on relationships between persons of different nationalities. That is, consumer animosity towards a country and their consequences are associated with political behaviour; consumers indirectly protest about international events. Both ethnocentrism and animosity would probably have some influence on consumer behaviour which is preceded by cognitive and affective aspects (Jiménez Torres and San Martín Gutiérrez, 2007: 4).

Witkowski (2000) studied U.S. consumers' animosity toward Chinese products and showed the negative impact of animosity on consumers' purchasing decision. Similarly, Ettenson and Klein (2005) analyzed the impact of Australian consumers' animosity on attitudes towards French goods: The results of study showed that Australian consumers' animosity toward France was negatively related to their willingness to purchase French products. On the other hand, Bahaee and Pisani (2009) investigated the relationship between Iranian consumers' animosity and U.S. products. The results suggested that the antecedent demographic variables of education, age and foreign travel experience are inversely related to 
consumer animosity whereas women and students tend to hold greater consumer animosity feelings than men and non-students. Additionally they found a strong and significant inverse relationship between Iranian consumer animosity and intention to buy U.S.-made products. However, in Turkey, the studies about consumer animosity and repurchase intent to the goods and services of foreign countries are rather few in number.

\section{Customer Loyalty}

At the heart of many firm strategies is the desire to develop and to maintain close relationships with customers. Accordingly, the creation of customer loyalty is a strategic objective for most company in global competitive markets. As customer loyalty may act as a barrier to customer switching behavior, it has an impact on the development of a sustainable competitive edge.

Oliver (1997) defines it as "a deeply held commitment to re-buy or re-patronize a preferred product/service consistency in the future, thereby causing repetitive same-brand or same brand-set purchasing, despite situational influences and marketing efforts having the potential to cause switching behavior." Customer loyalty is a function of perceived product superiority, personal fortitude, social bonding, trust, emotional attachment, and their synergistic effects (Ogba and Tan, 2009: 135; Pitta et al., 2006: 422). Moreover, Hwang and Wen (2009) suggest that customer loyalty depends on positive word-of-mouth, a resistance to switching, identification with the service, and a preference for a particular service provider among competition. The benefits of customer loyalty to a provider of either services or products include lower customer price sensitivity, reduced expenditure on attracting new customers; and improved organizational profitability (Rowley, 2005: 574).

Loyal customers are customers who hold favorable attitudes toward the company, commit to repurchase the product/service, and recommend the product to others (Bowen and Chen, 2001: 214). Loyal customers are less likely to switch to a competitor due to a given price inducement, and these customers make more purchases compared to less loyal customers (Wong and Sohal, 2003: 497).

There is a positive relationship between customer loyalty and repurchase intent to foreign goods and services. In this study, it will be analyzed whether customer loyalty as a moderate variable will reduce or not the impact of customer ethnocentrism and customer animosity on the repurchase intent to U.S goods and services.

\section{Repurchase Intent}

In this study, repurchase intention is accepted as dependent variable. Repurchase intention (RI) is defined the individual's judgment about buying again a designated service from the same company, taking into account his or her current situation and likely circumstances (Hellier et al., 2003: 1764). RI is one of the most appropriate dependent variable in any system of relationships designed to develop management insight and improved strategic planning and service delivery. Customers' repurchase intent depends on the value obtained in their previous transactions such as: appropriate performance criteria (benefits), competition, cost considerations, customer satisfaction (Olaru et al., 2008: 555), mood and past experiences, affect and perceived value, convenience and customer familiarity (Hume, 2008: 354).

As we (it is) explained above, this study is needed because the researches relevant to the relationship between consumer' animosity, consumer ethnocentrism and repurchase intent are limited. In this context, this study examines the effects of consumer ethnocentric tendencies and consumer animosity on repurchase intent. The following hypothesis will be tested in this respect: 
H1: Consumer ethnocentrism will be negatively related to repurchase intent.

$\mathrm{H} 2$ : Consumer animosity will be negatively related to repurchase intent.

H3: Consumer ethnocentrism will be positively related to consumer animosity.

H4: Customer loyalty will moderate the relationship between consumer ethnocentrism and repurchase intent.

H5: Customer loyalty will moderate the relationship between consumers' animosity and repurchase intent.

\section{About Figure 1}

\section{Methodology}

The sampling consists of Turkish consumers in supermarkets in the province of Nevşehir in Turkey. Interviewers were used to distribute questionnaires to 500 subjects. Of consumers who responded, 208 provided useable questionnaires on all study variables for a response rate of 41.6 per cent. This rate is an acceptable response rate for this kind of study (Özgener and İraz, 2006).

Repurchase intent was designated as the dependent variable in this study while consumer animosity, consumer ethnocentrism were considered as the independent variables. We used a 17-item scale called CETSCALE (Consumer Ethnocentric Tendencies SCALE) to assess consumers' ethnocentric tendencies developed by Shimp and Sharma (1987). The CETSCALE is comprised of 17 Likert-type items anchored by $1=$ strongly disagree and $7=$ strongly agree. The 14items CETSCALE instrument had reliability (Cronbach's alpha) of 0.93 . Usually, a value of 0.70 in the Cronbach's alpha is considered adequate in order to ensure reliability of the internal consistency of a questionnaire (Nunnally, 1978).
Similarly, we used three-item war animosity and four-item economic animosity adapted from Klein et al. (1998) for measuring animosity, Also, we used a single-item to measure general animosity developed by Klein et al. (1998). This scale is reliable (0.94). On the other hand, customer loyalty was measured via a nine-item scale. The questionnaire was adapted from Taylor et al. (2004) and modified to fit the Turkish supermarket industry. Participants responded on a 5-point Likert-type scale dictating to the extent which they agree with each statement as it reflected their present work environment $(1=$ strongly disagree, $5=$ strongly agree). The instrument had reliability (Cronbach's alpha) of 0.86 .

For measuring repurchase intent, a fouritem 5-point Likert scale ( 1 = strongly disagree, 5 = strongly agree) was adapted from Zeithaml et al. (1996), Cronin et al. (2000), Wang et al. (2004) and Pavlou (2003). The scale showed adequate reliability. The Cronbach's alpha coefficient was 0.94 .

\section{The Results}

The demographic profiles of Turkish consumers are presented in Table 1. The sample consisted of 122 (53.5 percent) females and 106 (46.5 percent) males. $52.6 \%$ of those responding had less than 25 ages. 36.0 percent of the respondents were married and 64.0 percent were single.

In terms of education levels, $2.5 \%$ of the respondents had graduated from primary school, $45.2 \%$ from secondary school, 30.0\% from high school, 25.4\% held Bachelor of Science degrees, and $12.7 \%$ had Master's degrees. Moreover, nearly half of the consumers had a foreign language $(58.3 \%)$ and only 18.0 of the respondents had to travel abroad. As students represent a very large majority $(41.7 \%)$ of the sample, we divided the occupation category into student and non-student. 
When household income levels are taken into consideration, it is seen that the respondents to the survey are taken place widely in level of lower class (30.7 percent), lower middle class (38.2 percent), upper middle class (25.4 percent) and upper class (5.7 percent) of the sample. The $63.6 \%$ of the respondents had a monthly income between TL 577 and TL 2500.

\section{About Table 1}

This study proposed a model for empirically analyzing the relations between consumer ethnocentrism, consumer animosity and repurchase intent towards U.S. products. Table 2 reports means, standard deviations, correlations among variables, and cronbach's alpha coefficients. As predicted, consumer ethnocentrism was positively related to consumer animosity $(\mathrm{r}=0.359$, $\mathrm{p}<0.01$ ), supporting H3. However, both consumer ethnocentrism $(\mathrm{r}=-0,214 ; \mathrm{p}<0.01)$ and consumer animosity $(\mathrm{r}=-0,259 ; \mathrm{p}<0.01)$ were found to be negatively related to customer loyalty. Similarly, consumer ethnocentrism $(\mathrm{r}=-0,378 ; \mathrm{p}<0.01)$ and consumer animosity $(\mathrm{r}=-0,371 ; \mathrm{p}<0.01)$ were negatively related to repurchase intent. Thus, $\mathrm{H} 1$ and $\mathrm{H} 2$ were supported. Moreover, customer loyalty was found to be positively related to repurchase intent at the 0.01 level. This result suggests that repurchase intent is largely a function of consumer loyalty.

\section{About Table 2}

Moderated hierarchical regression was used to test the hypotheses related to the constructs. Initially, the block of control variables were introduced into the model, followed by the appropriate independent and moderating variables. The variance inflation factors (VIFs) associated with each regression coefficient (ranging from 1,079 to 2,921 ) was all smaller than the suggested threshold of ten indicating that multicollinearity is not a problem (Morrow-Howell, 1994). In addition, correlations between variables ranged from 0.566 to -0.378 and were significant at a minimum level of 0.01 . Given that none of the bivariate correlations was greater than 0.80 , we can assume that multicollinearity is not a problem in data (Grewal et al., 2004).

In Model 1, control variables were entered in the analysis. The results in Table 3 suggest that the overall model was significant $(\mathrm{R} 2=0.111 ; \mathrm{F}(5$ $221)=5,499 ; \mathrm{p}<0.01)$. That means that $11.1 \%$ of the variance in repurchase intent was explained by the control variables. The results showed that only education had a significant effect on repurchase intent.

In Model 2, consumer ethnocentrism, consumer animosity and customer loyalty were entered in the analysis. Model 2 was statistically significant for repurchase intent $(\mathrm{R} 2=0.439 ; \mathrm{F}(8$ $218)=21,285 ; \mathrm{p}<0.01)$. As it can be observed, the regression coefficients representing the main effects of consumer ethnocentrism and consumer animosity on repurchase intent are negative and significant. The result showed that consumer ethnocentrism $(b=$ $-0.155 ; \mathrm{p}<0.01)$ and consumer animosity $(\mathrm{b}=$ $0.157 ; \mathrm{p}<0.01)$ were significant predictors of repurchase intent. But customer loyalty had a positive and significant effect on repurchase intent $(b=0.503 ; p<0.05)$. In model 2 , consumer ethnocentrism, consumer animosity and customer loyalty explained additional 32.8 percent of the variance in repurchase intent.

\section{About Table 3}

Model 3 includes the interaction effects on repurchase intent. The results showed that Model 3 was significant $\quad(\mathrm{R} 2=0.491 ; \quad \mathrm{F}(10-216)=20,877$; $\mathrm{p}<0.01$ ). Model 3 showed that the interaction of consumer ethnocentrism and customer loyalty was positive and significant on repurchase intent $(b=$ $0.849 ; \mathrm{p}<0.01)$. Thus, $\mathrm{H} 4$ was supported. That is to

The Effects Of Consumer Ethnocentrism And Consumer Animosity On The Re-Purchase Intent: The Moderating Role Of Consumer Loyalty 
say, customer loyalty moderated only the relationship between consumer ethnocentrism and repurchase intent. However, the interaction of consumers animosity and customer loyalty had a positive but not statistically significant effect on repurchase intent $(b=0,125 ; p>0.01)$. Thus, H5 was not supported. Customer loyalty did not moderate the relationship between consumer' animosity and repurchase intent. The interaction term explained additional 5.3 percent of the variance in repurchase intent.

\section{Conclusion}

World economies are very much dependent on each other. When one economy suffers, it is unavoidable that other countries' economies will be affected by the crisis, which in turn affects international trade and multinational companies' behaviours. Moreover, when there is an economic and political crisis, it is possible that consumers give more priority to the purchase of local products. Therefore, international trade activities are becoming a central part of the world economy, and it is recognized that there is a greater necessity to predict consumers' attitudes toward both domestic and foreign products. Thus the relationships between consumer' attitudes (consumer animosity and consumer ethnocentrism) and repurchase intent are in need of investigation. Particularly, consumer animosity and ethnocentrism are strong in developing countries such as Turkey. However, little research has investigated the relationships between ethnocentrism and consumers' animosity toward foreign products in developing countries.

Consumer animosity and consumer ethnocentrism have gained considerable attention in strategic marketing literature as components of foreign product purchase behaviour. Through the results of this study, we contribute to a better understanding of how multinational companies may effectively overcome the complex problems or dilemma to consumer animosity and consumer ethnocentrism. Thanks to the findings of the study, managers of multinational companies could do well to manage marketing efforts or at least not take severe steps that may be difficult to reverse.

This research investigated the impact of consumer animosity and consumer ethnocentrism on repurchase intent. Previous studies suggested that consumer ethnocentrism was positively related to consumer animosity (Rose et al., 2009). In parallel with the previous studies, we identified a significant and positive relation between consumer ethnocentrism and consumer animosity. However, both consumer ethnocentrism and consumer animosity were found to be negatively related to customer loyalty for the sampling. At the same time, consumer ethnocentrism and consumer animosity were found to be negatively related to repurchase intent toward U.S. products, which is consistent with the findings of Witkowski (2000), Ettenson and Klein (2005), and Bahaee and Pisani (2009). The anticipated negative effect of attitude towards U.S. products was confirmed. Furthermore, customer loyalty was found to be positively related to repurchase intent.

According to the results of regression analyses, customer loyalty may not be an important moderating factor between consumers' animosity and repurchase intent toward U.S. products. However, the findings of this study show that customer loyalty has a moderator effect on the interaction of consumer ethnocentrism and repurchase intent toward U.S. products. Therefore, it plays a crucial role in providing repurchase intent

The overall results show that animosity and consumer ethnocentrism significantly affect the willingness to purchase U.S. products. That is, the findings of this study suggest that when deciding on purchasing a product, some Turkish consumers are less likely to consider products and services of U.S. companies. The present study also denotes that both consumer ethnocentrism and animosity have a 
negative impact on repurchase intent toward U.S. products in Turkey. This suggests that U.S companies and multinational companies in Turkey should pay more attention to Turkish nationalistic tendencies.

The findings of this study need to be interpreted with the following limitations in mind. First limitation is that the results cannot be construed to be representative of all consumers in supermarkets around the world due to the highly limited nature of the sample. Second, because these findings may be subject to cultural and economics factors, there is also a need to replicate the study in cultural and economic contexts that differ from the present one. Third, the majority of the respondents could be reported drastic negative views due to U.S. supporter attitude of Armenia related to TurkishArmenian political problems.

Future research should test the effect of perceived quality on the relationships between consumer animosity and repurchase intent. In addition, in the aspect of sampling respondents, this study selected only Turkish consumers in supermarkets in the province of Nevşehir-Turkey. Follow-up studies can extend this scope to other consumer groups. Finally, it would be interesting to test the proposed model in several product categories. 


\section{References}

1. Bahaee, M. and Pisani, M. J. (2009), Iranian consumer animosity and U.S. products: A witch's brew or elixir?, International Business Review 18: 199-210.

2. Bowen, J. T. and Chen, S. (2001), The relationship between customer loyalty and customer satisfaction, International Journal of Contemporary Hospitality Management 13 (5): 213-217

3. Cronin, J. J., Brady, M. K. and Hult, G. T. M. (2000). Assessing the effects of quality, value, and customer satisfaction on consumer behavioral intentions in service environments, Journal of Retailing, 76(2): 193-218.

4. Ettenson, R. and Klein, J. G. (2005), The fallout from French nuclear testing in the South Pacific: A longitudinal study of consumer boycotts, International Marketing Review, 22 (2): 199-224.

5. Evanschitzky, H., Wangenheim, F.V., Woisetschla, D. and Blut, M. (2008), Consumer ethnocentrism in the German market, International Marketing Review, 25 (1): 7-32.

6. Grewal, R., Cote, J. A. and Baumgartner, H. (2004). Multicollinearity and measurement error in structural equation models: implications for theory testing. Marketing Science, 23 (4). 519-530.

7. Hellier, P. K., Geursen, G. M., Carr, R. A. and Rickard, J. A. (2003), Customer repurchase intention: A general structural equation model, European Journal of Marketing, 37 (11/12): 1762-1800.

8. Herche, J. (1994), Ethnocentric Tendencies, Marketing Strategy and Import Purchase Behaviour, International Marketing Review, 11 (3): 4-16.

9. Hume, M. (2008). Understanding core and peripheral service quality in customer repurchase of the performing arts, Managing Service Quality, 18 (4): 349-369.

10. Hwang, J. and Wen, L. (2009), The effect of perceived fairness toward hotel overbooking and compensation practices on customer loyalty, International Journal of Contemporary Hospitality Management, 21 (6): 659675.

11. Jiménez Torres, N. H. and San Martín Gutiérrez, S. (2007), The purchase of foreign products: The role of firm's country-of-origin reputation, consumer ethnocentrism, animosity and trust. Universidad de Burgos.Documento de trabajo 13/07, October.

12. Jimenez, N. H. and San Martin, S. (2010), The role of country-of-origin, ethnocentrism and animosity in promoting consumer trust. The moderating role of familiarity, International Business Review, 19 (1): 34-45.

13. Klein, J. G., Ettenson, R. and Morris, M. D. (1998), The Animosity Model of Foreign Product Purchase: An Empirical Test in the People's Republic of China, The Journal of Marketing, 62 (1): 89-100.

The Effects Of Consumer Ethnocentrism And Consumer Animosity On The Re-Purchase Intent: The Moderating Role Of Consumer Loyalty Emerging Markets Journal | P a g e | 8 
14. Klein, J. G. and Ettenson, R. (1999) Consumer animosity and consumer ethnocentrism, Journal of International Consumer Marketing, 11 (4): 5-24.

15. Morrow-Howell, N. (1994). The M word: multicollinearity in multiple regressions. Social Work Research,18 (4), 247-251.

16. Netemeyer, R., Durvasula, S. and Lichtenstein, D. (1991), A cross-national assessment of the reliability and validity of the CETSCALE, Journal of Marketing Research, 28 (August): 320-327.

17. Nijssen, E. J. and Douglas, S. P. (2004), Examining the animosity model in a country high level of foreign trade, Intern. J. of Research in Marketing, 21: 23-38.

18. Nunnally, J. (1978), Psychometric Theory (McGraw-Hill, New York).

19. Ogba, I. and Tan, Z. (2009), Exploring the impact of brand image on customer loyalty and commitment in China, Journal of Technology Management in China, 4 (2): 132-144.

20. Olaru, D. Purchase, S., and Peterson, N. (2008), From customer value to repurchase intentions and recommendations, Journal of Business \& Industrial Marketing 23(8): 554-565.

21. Oliver, R. (1997), Satisfaction: A Behavioral Perspective on the Consumer, McGraw-Hill, New York, NY.

22. Özgener, Ş. and İraz, R. (2006), Customer relationship management in small-medium enterprises: The case of Turkish tourism industry, Tourism Management 27: 1356-1363.

23. Pavlou, P. A. (2003), Consumer acceptance of electronic commerce: integrating trust and risk with the technology acceptance model, International Journal of Electronic Commerce, 7 (3): 101-34.

24. Pitta, D., Franzak, F. and Fowler, D. (2006), A strategic approach to building online customer loyalty: integrating customer profitability tiers, Journal of Consumer Marketing, 23 (7): 421-429.

25. Riefler, P. and Diamantopoulos, A. (2007), Consumer animosity: a literature review and a reconsideration of its measurement, International Marketing Review, 24 (1): 87-119.

26. Rose, M., Rose, G. M. and Shoham, A. (2009), The impact of consumer animosity on attitudes towards foreign goods: a study of Jewish and Arab Israelis, Journal of Consumer Marketing, 26 (5): 330-339.

27. Rowley, J. (2005), The four Cs of customer loyalty, Marketing Intelligence \& Planning, 23 (6): 574-581.

28. Shimp, T. A. and Sharma, S. (1987,). Consumer ethnocentrism: construction and validation of the CETSCALE. Journal of Marketing Research, 24: 280-289.

29. Taylor, S. A., Celuch, K. and Goodwin, S. (2004), The importance of brand equity to customer loyalty, Journal of Product \& Brand Management, 13 (4): 217-227. 
30. Wang, Y., Lo, H. P. and Yang, Y. (2004). An integrated framework for service quality, customer value, satisfaction: Evidence from China's telecommunication industry. Information Systems Frontiers, 6(4): 325340.

31. Witkowski, T. (2000), 'Effects of animosity toward China on willingness to buy Chinese products'. In G. McClean, E. Kaynak, and O. Aliagra (Eds.), Managing in a turbulent international business environment (pp. 470-477). Hammelstown, PA: The International Management Development Association.

32. Wong, A. and Sohal, A. (2003), Service Quality and customer loyalty perspectives on two levels of retail relationships, Journal of Services Marketing, 17 (5): 495-513.

33. Zeithaml, V. A., Berry, L. L. and Parasuraman, A. (1996). The behavioral consequences of service quality. Journal of Marketing, 60(2): 31-46. 


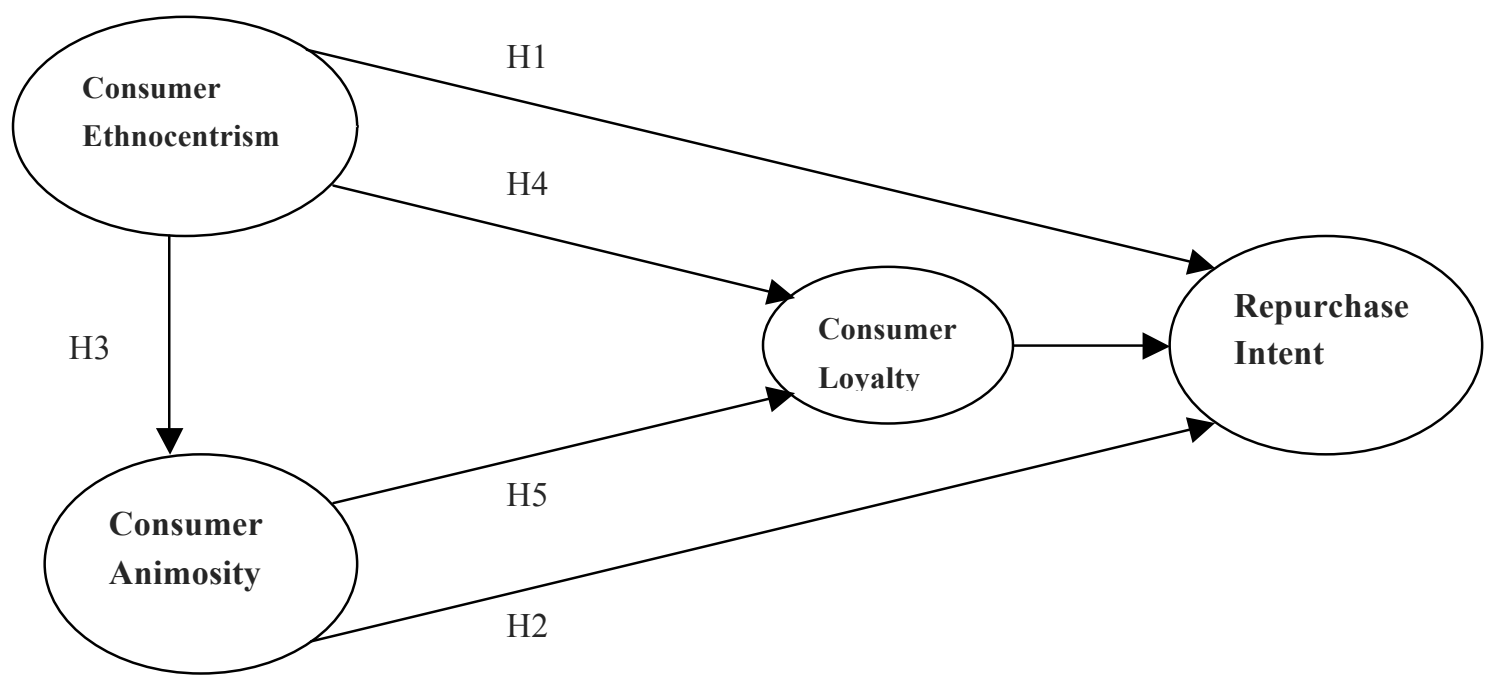

Figure 1: Research Model

Table 1: Descriptive Statistics of Turkish consumers

\begin{tabular}{|l|l|l|l|l|l|}
\hline Demographic Characteristics & f & $\mathbf{( \% )}$ & Demographic Characteristics & f & $\mathbf{( \% )}$ \\
\hline Gender & & & Education Level of Consumers & & \\
Female & 122 & 53.5 & Primary school & 8 & 3,5 \\
Male & 106 & 46.5 & Secondary school & 103 & 45,2 \\
Marital Status & & & High school & 30 & 13,2 \\
Married & 82 & 36.0 & Master's degree or PhD & 58 & 25,4 \\
Single & 146 & 64.0 & & 29 & 12,7 \\
Age & & & Monthly household income level & & \\
Less than 25 & 120 & 52,6 & Lower class (576 <) & 70 & 30,7 \\
$26-30$ & 40 & 17,5 & Lower middle class (577-1500) & 87 & 38,2 \\
$31-35$ & 24 & 10,5 & Upper middle class (1501-2500) & 58 & 25,4 \\
$36-40$ & 24 & 10,5 & Upper class (>2501) & 13 & 5,7 \\
31 or more & 20 & 8,8 & & & \\
Average household size- & & & Occupation & Student & \\
\hline
\end{tabular}

The Effects Of Consumer Ethnocentrism And Consumer Animosity On The Re-Purchase Intent: The Moderating Role Of Consumer Loyalty 


\begin{tabular}{|c|c|c|c|c|c|}
\hline number of people & & & Non-student & 133 & 58,3 \\
\hline Less than 2 & 39 & 17,1 & & & \\
\hline $3-5$ & 146 & 64,0 & Foreign Language Education of & & \\
\hline 6-8 & 36 & 15,8 & Consumers & & \\
\hline $9-11$ & 3 & 1,3 & Yes & 133 & 58,3 \\
\hline 12 or more & 4 & 1,8 & No & 95 & 41,7 \\
\hline & & & Foreign Travel Level of Consumers & & \\
\hline & & & Yes & 41 & 18.0 \\
\hline & & & No & 187 & 82.0 \\
\hline
\end{tabular}

Table 2: Descriptive statistics and intercorrelations among study variables

\begin{tabular}{|l|l|l|llll|}
\hline Variables & $\begin{array}{l}\text { Mea } \\
\mathbf{n}\end{array}$ & $\begin{array}{l}\text { Std. } \\
\text { Deviatio } \\
\mathbf{n}\end{array}$ & $\mathbf{1}$ & $\mathbf{2}$ & $\mathbf{3}$ & $\mathbf{4}$ \\
\hline $\begin{array}{l}\text { 1.Consumer } \\
\text { Ethnocentrism } \\
\text { 2. Consumer Animosity }\end{array}$ & 3,19 & 0,84 & $(0.93)$ & & \\
3. Customer Loyalty & 2,07 & 0,71 &,$- 214(* *)$ &,$- 259(* *)$ & $(0.86)$ & \\
4. Repurchase Intent. & 2,05 & 0,93 &,$- 378(* *)$ &,$- 371(* *)$ &, $566(* *)$ & $(0.94)$ \\
\hline
\end{tabular}

** Correlation is significant at the 0.01 level (2-tailed). 